\title{
Sources, deposition flux and carcinogenic potential of PM2.5-bound polycyclic aromatic hydrocarbons in the coastal zone of the Baltic Sea (Gdynia, Poland)
}

\author{
Karolina Skalska ${ }^{1} \cdot$ Anita Urszula Lewandowska $^{2}$ (D) $\cdot$ Marta Staniszewska $^{2} \cdot$ Andrzej Reindl $^{2} \cdot$ Agnieszka Witkowska $^{2}$. \\ Lucyna Falkowska ${ }^{2}$
}

Received: 12 May 2019 / Accepted: 20 August 2019/Published online: 5 September 2019

(C) The Author(s) 2019

\begin{abstract}
Concentrations of 16 PAHs of different molecular weight and carcinogenic potency were measured in PM2.5 aerosols collected in the coastal zone of southern Baltic Sea (Gdynia, Poland) during the end of the heating and beginning of the non-heating season of 2012. Obtained results showed that coal combustion (pyrogenic source) contributed to the highest emission of PAHs during the heating season. However, similar concentrations of highly carcinogenic PAHs were detected in the non-heating period. The analysis of prevailing wind directions, air mass trajectories and diagnostic PAH ratios revealed that in addition to land transport emission (mainly from diesel vehicles), the increase in sea shipping traffic during the non-heating season contributed to the high concentrations of detected carcinogenic PAHs. We conclude that the increasing maritime activity in the southern Baltic Sea region might have an adverse effect on both environmental and human health. Therefore, it should receive more attention by the Polish government as a pollutant source.
\end{abstract}

Keywords PM2.5 $\cdot$ PAHs $\cdot$ Diagnostic ratios $\cdot$ Deposition flux $\cdot$ BaP-TEQ

\section{Introduction}

Polycyclic Aromatic Hydrocarbons (PAHs) are a group of organic compounds composed of more than one aromatic ring. They are typically classified according to their mass, with the division into low (2-3 benzene rings), medium (4 benzene rings) and high ( $5-6$ benzene rings) molecular weight compounds being the most common (Ravindra et al. 2008). PAHs' molecular weight and chemical structure determine their characteristics. Lighter compounds are volatile and primarily present in gaseous phase. Hence, they are widely dispersed in the atmosphere and can be washed out by rain (Karali et al. 2018). Heavier compounds, on the other hand, are characterised by a higher affinity towards solid phase and can get readily adsorbed on particulate matter, which increases

Anita Urszula Lewandowska

a.lewandowska@ug.edu.pl

1 School of Environment and Technology, University of Brighton, Brighton BN2 4GJ, UK

2 Institute of Oceanography, University of Gdansk, Al. Marszałka J. Piłsudskiego 46, 81-378 Gdynia, Poland their persistence in the environment. The latter have been of major scientific interest due to their well-documented carcinogenicity, genotoxicity and potential for DNA damage (Błaszczyk and Mielżyńska-Švach 2016). It has been reported that over $95 \%$ of particle-phase PAHs are associated with particulate matter of less than $3 \mu \mathrm{m}$ in diameter. Such aerosols can easily penetrate the human respiratory tract, and, in the case of sub-micron particulates, enter the blood stream. That, in turn, leads to PAH-initiated carcinogenesis via the formation of PAH-DNA adducts (Liu et al. 2015).

Although PAHs are often associated with anthropogenic emission (e.g. burning of coal or gas), they can also originate from natural sources, such as forest fires or volcanic eruptions. Anthropogenic sources include combustion processes (pyrogenic PAHs) and maturation of crude oil (petrogenic PAHs) (Ravindra et al. 2008). Because these processes result in an emission of specific PAHs, individual sources can be distinguished using the diagnostic ratio method (Tobiszewski and Namiesnik 2012). Irrelevant of the source, PAHs are always emitted as a mixture rather than individual compounds (Ravindra et al. 2008). The diagnostic ratio method uses the relative concentrations of PAH pairs of the same molecular weight and properties (isomers), which are thought to represent specific emission sources (e.g. petroleum combustion or fuel 
burning). A total of 16 priority PAH species, nevertheless, the isomer ratio method has been widely used to determine sources of PAHs in a range of different matrices, e.g. air, water, soil or marine organisms (Tobiszewski and Namiesnik 2012).

High concentrations of PAHs are commonly noted in urban regions, where they originate from burning fossil fuels, vehicle combustion engines, as well as from the industrial sector. Whereas west European countries are converting to green energy sources, eastern nations (i.e. Bulgaria, Poland, Czech Republic, Slovakia) still rely on fossil fuel combustion to generate electricity and heat (Garrido et al. 2014). As a consequence, PAH levels in well-developed western European countries rarely exceed the set threshold values, while their elevated concentrations are frequently noted in Eastern Europe (EEA 2018). Of all European countries, Poland is often referred to as 'Europe's capital of smog'. With air contamination showing no signs of improvement and the current government's ongoing investments in coal mining, it remains one of the most polluted countries in Europe. According to European Environment Agency, Poland currently has the highest levels of $\mathrm{BaP}$ relative to other European countries, with $87 \%$ of the total PAH emission resulting from domestic coal and wood burning (EEA 2018). High concentrations of $\mathrm{BaP}$ (in PM10) are routinely detected all over Poland; however, its highest levels (as high as $22.7 \mathrm{ng}$ $\mathrm{m}^{3}$ in 2017) are often noted in central and southern parts of the country (Iwanek et al. 2016), partially due to the local topography. Southern Poland is dominated by mountainous terrains, which results in the trapping of contaminants in adjacent air. Its northern part, on the other hand, is located near the Baltic Sea, which facilitates an effective dispersal of air pollutants (Lewandowska et al. 2018a). Air pollution is often associated with rural areas, as a result of using low-quality coal and outdated furnaces for heat generation in individual households. The practice of burning garbage (e.g. plastic bottles or car tires) instead of coal in efforts to save money is also welldocumented (Lewandowska et al. 2018b). Due to domestic heating being a large contributor to air pollution, seasonal variability in PAHs concentration has been reported by several authors in Poland, with elevated levels of contaminants in the autumn/winter period (e.g. Ćwiklak et al. 2009; Iwanek et al. 2016; Lewandowska et al. 2018b). Another potential source of PAHs is the emission of exhaust gases and particulates from diesel engines. It is well-acknowledged that diesel engines contribute to the emission of both semi-volatile and particlebound hydrocarbons (Yilmaz and Davis 2016). An average Polish car has been reported to be 13 years old, suggesting that Poland has the oldest vehicles in European Union (ACEA 2017).

With that many sources significantly contributing to the problem of air pollution, it is vital to monitor the levels of PAHs in the air and recognise their sources of origin to drive measures to reduce their emission. This is especially important for contaminants associated with smaller particles, which have been found to be hazardous to human health (Liu et al. 2015). Therefore, the purpose of this study was to assess the variability of PM2.5-bound PAHs concentration in the late heating and the early non-heating period (April-May of 2012) in Gdynia, located in the coastal zone of the southern Baltic Sea. Thorough analysis of air mass trajectories and quantification of PAH diagnostic ratios allowed identification of potential sources of PAHs in the collected aerosol samples. Moreover, an effort was made to estimate the deposition fluxes and the overall carcinogenic potential of 16 priority PAHs emitted over the analysed period.

\section{Materials and methods}

\section{Sampling site}

Aerosol sampling was conducted in Gdynia, Poland (Fig. 1). Located on the southern coast of the Baltic Sea, Gdynia is part of the urbanised area named the Tri-city, along with Sopot and Gdansk (Lewandowska et al. 2018a). It currently has a population of approximately 250,000. PM2.5 aerosols were collected using a sampling device located on the roof of the Institute of Oceanography (University of Gdansk; $54.51^{\circ} \mathrm{N} ; 18.54^{\circ} \mathrm{E}$ ), about $560 \mathrm{~m}$ from the seashore. The sampling point was positioned at $20 \mathrm{~m}$ a.s.l., in close proximity to the busy roads of the city centre, as well as the local seaport, the Gdansk Shipyard and a bypass with high daily traffic including freight-hauling trucks (approx. $3 \mathrm{~km}$ and $6 \mathrm{~km}$ away, respectively). Other air pollution sources in the Gdynia region include domestic heating, maritime activity and agriculture (Witkowska and Lewandowska 2016; Lewandowska et al. 2018a).

\section{Sample processing and chemical analysis of PAHs}

PM2.5 samples were collected throughout April and May 2012 (April 16, 2012-May 15, 2012) using FAI Hydra Dual Sampler operating at a flow rate of $2.3 \mathrm{~m}^{3} \mathrm{~h}^{-1}$. Particulate matter was collected on QMA Whatman quartz filters $(\varphi=47 \mathrm{~mm})$. Prior to aerosol sampling, all filters were pre-combusted in a muffle furnace for at least $6 \mathrm{~h}$ at $550{ }^{\circ} \mathrm{C}$ and weighed $\left(10^{-5} \mathrm{~g}\right.$ precision, $T=23 \pm 2{ }^{\circ} \mathrm{C}$ and air humidity of $40 \pm 5 \%$ ). After sample collection, filters were weighed again and kept in a desiccator under the same conditions as before sampling. The mass of collected particulate matter was determined by subtracting the pre-sampling mass of the filter from its post-sampling total weight. This value was later divided by the volume of air that passed through the sampling device, enabling a precise quantification of PM2.5 concentration in a parcel of air. The limit of detection was estimated at $0.17 \mu \mathrm{g} \mathrm{m}^{-3}$, and the estimated error quantified for 28 blank 


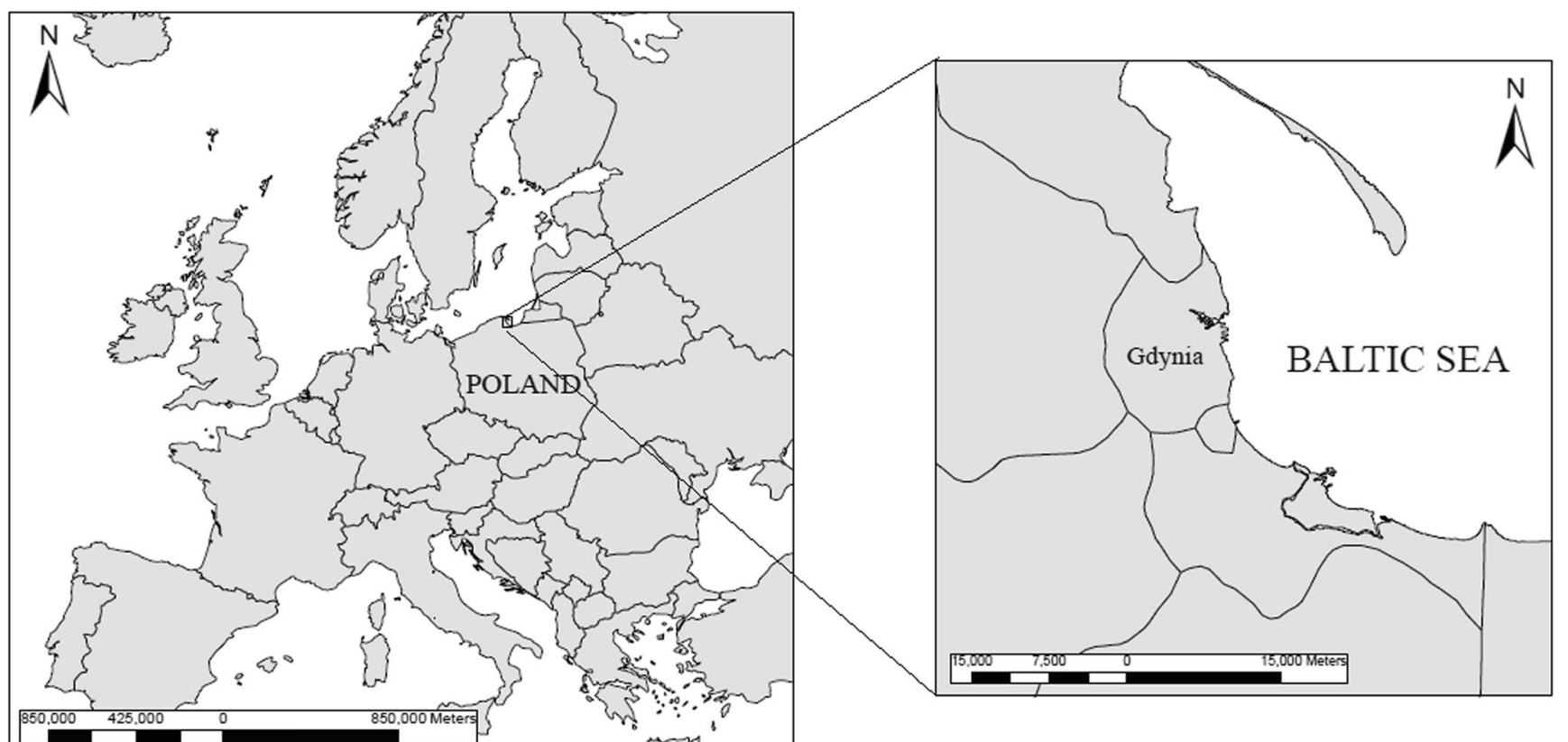

Fig. 1 Location of the sampling site (Gdynia, Poland)

samples $(p=0.99)$ was around $4.1 \%$ (Witkowska and Lewandowska 2016; Lewandowska et al. 2018a).

Prior to the analysis, a portion $(\varphi=2.5 \mathrm{~cm})$ of the filter was cut out. Sixteen priority PAHs were extracted using the Soxhlet apparatus and a 1:1 mixture of toluene and methanol $\left(250 \mathrm{~cm}^{3}\right)$ as solvent. The extraction was conducted over $8 \mathrm{~h}$, with a frequency of $6-8$ cycles per hour. Solvents were later evaporated from the extracts using a rotary evaporator, and the obtained liquid was purified by solid-phase extraction using Florisil magnesium silica cartridges (ThermoScientificHyperSep). At this stage, the 1:1 mixture of toluene and methanol was used as eluent. The obtained eluate was concentrated to $1 \mathrm{~cm}^{3}$ using a nitrogen evaporative concentrator. All of the samples were analysed using the Agilent 1200 Series HPLC System with a diode array detector. A solution of acetonitrile and Merck MilliQ water (8:2) was used as liquid phase, and the analytes were subsequently separated using Hypersil Green columns. A total of 16 priority PAH species were analysed (identified according to the obtained spectra and retention time): naphthalene (NAP), acenaphthylene (ACY), acenaphthene (ACE), fluorene (FLU), phenanthrene (PHE), anthracene (ANT), fluoranthene (FLA), pyrene (PYR), benzo(a)anthracene (BaA), chrysene (CHR), benzo(b)fluoranthene (BbF), benzo(k)fluoranthene $(\mathrm{BkF})$, benzo(a)pyrene $(\mathrm{BaP})$, indeno(1,2,3-c,d)pyrene (IcdP), dibenzo(a,h)anthracene (DahA) and benzo(g,h,i)perylene (BghiP). The limit of detection was quantified at $0.001 \mathrm{pg} \mathrm{cm}^{-3}$ (FLA) to $0.05 \mathrm{pg} \mathrm{cm}^{-3}$ (NAP), whereas the average recovery was estimated to be between 87 and $93 \%$.

\section{Weather conditions and air-mass back trajectories}

Meteorological data has been collected throughout the entire sampling period using the Vaisala MILOS 500 weather station. Several variables were taken into consideration, including wind velocity and direction, air temperature and relative humidity, as well as the volume of precipitation. Basic statistics acquired are shown in Table 1. Wind roses were generated for both the heating and non-heating season.

Additionally, 48-h air mass back trajectories were computed using the NOAA HYSPLIT Model (Stein et al. 2015) for each day, using 6-h intervals and arrival heights of 500, 1000 and $1500 \mathrm{~m}$. Where trajectories were found to differ significantly, additional maps were created using the arrival height of the sampling location and 3-h time intervals. The method used was described in detail by Witkowska and Lewandowska (2016).

\section{Data analysis}

Statistical calculations of average, maximum and minimum values as well as standard deviations were made using the STATISTICA $®$, R and EXCEL $®$ software, which was also used for the determination of linear regression coefficients, the standardisation of data and the graphic presentation of results. In order to determine statistically significant differences in more than two sets of independent and nonparametric data, the Kruskal-Wallis test was used. For all dependencies presented in the publication, the level of significance $(p)$ was established at less than 0.05 . 
Table 1 Meteorological data obtained in Gdynia throughout 16/04/2012-15/05/2012

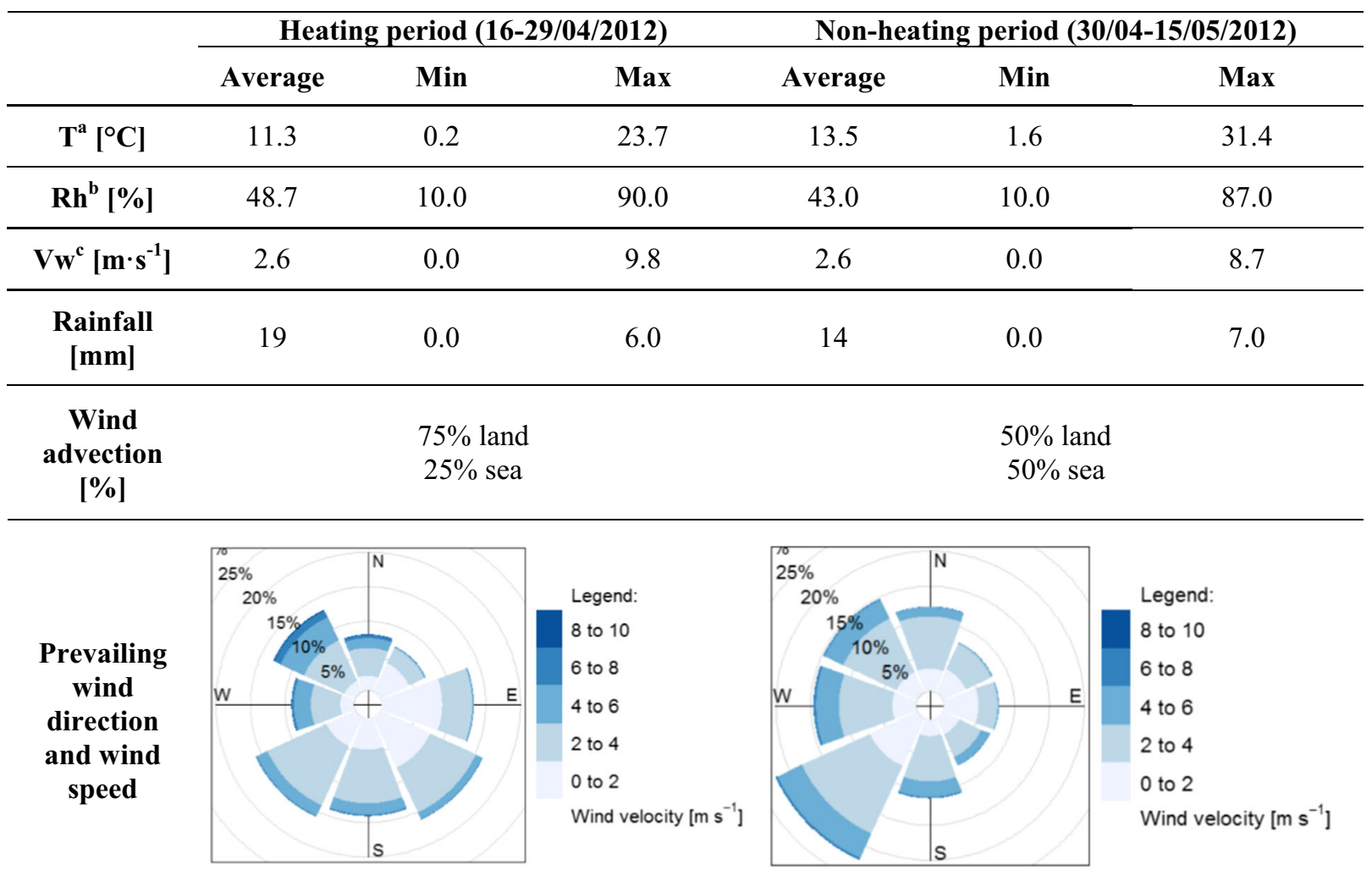

$T$, air temperature; $V w$, wind velocity; $R h$, relative humidity

\section{Quantification of dry deposition flux}

The equation proposed by Seinfeld and Pandis (2016) was used to calculate the dry deposition flux of PM2.5-bound PAHs:

$I_{a}=V_{d} \times C$

where $I_{a}$ corresponds to the dry deposition flux of aerosols [g $\left.\mathrm{m}^{-2} \mathrm{~s}^{-1}\right], V_{d}$-deposition velocity of aerosols $\left[\mathrm{m} \mathrm{s}^{-1}\right]$ and $C-$ concentration of aerosols, or the adsorbed pollutant $\left[\mathrm{g} \mathrm{m}^{-3}\right]$. Based on the value estimated by Rodhe et al. (1980), the deposition velocity of PM2.5 aerosols was assumed to be roughly $0.005 \mathrm{~m} \mathrm{~s}^{-1}$.

\section{Quantification of BaP-equivalent}

The Benzo(a)Pyrene Equivalent (BaPE) is a parameter commonly used to assess the relative human health risk associated with exposure to carcinogenic PAHs. It is quantified based on the average measured concentrations of PAHs characterised by a high carcinogenic/mutagenic potential (Ladji et al. 2014). The following equation was used:

$$
\begin{aligned}
\mathrm{BaPE}= & 0.06 \times \mathrm{BaA}+0.07 \times \mathrm{BF}+\mathrm{BaP}+0.6 \\
& \times \mathrm{DahA}+0.06 \times \mathrm{IcdP} .
\end{aligned}
$$

\section{Results and discussion}

\section{Variations of PM2.5 concentrations in the atmosphere over Gdynia}

The average daily mass concentration of PM2.5 aerosols obtained in Gdynia in the study period (April 16, 2012-May 15, 2012) was $37.37 \mu^{-3} \mathrm{~m}^{-3}$. This is in agreement with concentrations previously reported for the Tri-city at this time of year (e.g. $33.02 \mathrm{\mu gm}^{-3}$ for October 2009-March 2010 reported by Rogula-Kozłowska and coauthors (Rogula-Kozłowska et al. 2014), as well as for other European cities (Eeftens et al. 2013). Although PM2.5 levels were not monitored in Gdynia during the investigated period, much lower concentrations were noted in Gdansk ( $11.50 \mu \mathrm{g} \mathrm{m}^{-3}$, average calculated for the same period), located $16 \mathrm{~km}$ from the study area. Concentrations of PM2.5 reported by the Chief Inspectorate of Environmental Protection were also much lower at other Tri-city stations (average of $16.05 \mu \mathrm{g} \mathrm{m}^{-3}$ ) (2012 archived data, http://powietrze.gios.gov.pl/pjp/archives). This was unusual, as elevated PM2.5 levels are predominantly noted in southern Poland due to domestic heating and the excessive use of fossil fuels, especially coal (RogulaKozłowska et al. 2014). For instance, Styszko and coauthors (Styszko et al. 2017) reported PM2.5 concentrations as high as $84.1 \mathrm{\mu g} \mathrm{m}^{-3}$ in Poland's second largest city, 
Krakow (Malopolska Voivodeship, SE Poland). It is possible that the relatively high PM2.5 levels noted in Gdynia resulted from the station being situated right next to a busy street. This could have caused a higher load of particulate matter received by the sampler. In addition, repair works were being undertaken at a street situated near the study location, potentially causing an increase in PM2.5 concentrations. Nevertheless, the impact of domestic heating was largely pronounced, with the average mass concentration of PM2.5 in the heating period being significantly higher $\left(41.70 \mathrm{\mu g} \mathrm{m}^{-3}\right)$ than the one measured in the non-heating season $\left(34.85 \mu \mathrm{g} \mathrm{m}^{-3}\right)$, as confirmed by the Kruskal-Wallis ANOVA test $(p=0.0124)$. The maximum average daily value $\left(51.70 \mu \mathrm{g} \mathrm{m}^{-3}\right)$ was observed during the non-heating period (Table 2), which was most likely the result of heating still taking place in individual households. Indeed, air temperatures were only slightly higher in the nonheating season compared to the period of active heating, with minimum values of $1.6^{\circ} \mathrm{C}$ and $0.2^{\circ} \mathrm{C}$, respectively. Moreover, the natural emission of aerosols due to the re-awakening of plant vegetation on land and in the sea could have contributed to the elevated PM2.5 concentrations in the non-heating period (Hoyle et al. 2011). The maximum temperature in April was $23.7{ }^{\circ} \mathrm{C}$, and a high of $31.4{ }^{\circ} \mathrm{C}$ was reported in May (Table 1), which could have facilitated the oxidation of volatile organic compounds (VOCs) and subsequent generation of secondary organic aerosols (SOAs) (Sánchez de la Campa et al. 2009). With the average wind speed of $2.6 \mathrm{~m} \mathrm{~s}^{-1}$, it is likely that the regional source of aerosols prevailed during both, heating and non-heating periods (Lewandowska et al. 2018a). The low wind speed combined with the dominant wind direction from the south west might suggest that aerosols were advected from the Kashubian region, where low temperatures (relative to Gdynia) are reported during early spring and individual heating systems are prevalent. That, in turn, typically results in an increased emission of air pollutants. Moreover, the relatively low precipitation in the heating period could have prevented the wash-out of particulates from the air.

\section{Changes in PAHs concentration in PM2.5 in the atmosphere over Gdynia}

It is well-established that particulate-bound PAHs display strong seasonal variations due to the presence or absence of combustion sources. Indeed, the mean $\sum \mathrm{PAH}_{16}$ concentration obtained in the non-heating season $\left(9.40 \mathrm{ng} \mathrm{m}^{-3}\right)$ was slightly lower than that quantified for the heating period (12.56 ng $\mathrm{m}^{-3}$ ) (Table 2). These values are comparable to these reported by Martellini and co-authors (Martellini et al. 2012), who found PM2.5-bound $\sum \mathrm{PAH}_{16}$ concentrations to range between 0.76 and 17 (winter) to 0.46 and $10 \mathrm{ng} \mathrm{m}^{-3}$ (summer) at an urban location in Italy (Florence, Tuscany). Much lower concentrations are reported for warmer regions of Europe that rely on coal and biomass combustion to a much lower extent
Table 2 Mass concentrations of PM2.5 $\left[\mathrm{\mu g} \mathrm{m}^{-3}\right]$ and PAHs $\left[\mathrm{ng} \mathrm{m}^{-3}\right]$ obtained in Gdynia throughout April 16-May 15, 2012

\begin{tabular}{|c|c|c|c|}
\hline & Compound & $\begin{array}{l}\text { Heating period } \\
\text { (April 16-April 29, } \\
\text { 2012) }\end{array}$ & $\begin{array}{l}\text { Non-heating period } \\
\text { (April 30-May 15, } \\
\text { 2012) }\end{array}$ \\
\hline & PM2.5 & $\begin{array}{l}34.85 \pm 6.91 \\
(26.30-48.70)\end{array}$ & $\begin{array}{l}41.7 \pm 7.40 \\
(28.80-51.70)\end{array}$ \\
\hline \multirow[t]{6}{*}{ LMW } & Naphtalene & $\begin{array}{l}3.89 \pm 3.71 \\
(0.15-10.27)\end{array}$ & $\begin{array}{l}0.24 \pm 0.12 \\
(0.15-0.32)\end{array}$ \\
\hline & Acenaphtylene & $\begin{array}{l}5.96 \pm 4.23 \\
(1.02-11.70)\end{array}$ & $\begin{array}{l}2.42 \pm 1.31 \\
(0.70-3.77)\end{array}$ \\
\hline & Acenaphtalene & $\begin{array}{l}0.53 \pm 0.42 \\
(0.18-1.50)\end{array}$ & $\begin{array}{l}0.30 \pm 0.19 \\
(0.12-0.56)\end{array}$ \\
\hline & Fluorene & $\begin{array}{l}0.26 \pm 0.21 \\
(0.03-0.65)\end{array}$ & $\begin{array}{l}0.06 \pm 0.1 \\
(0.01-0.27)\end{array}$ \\
\hline & Phenantrene & $\begin{array}{l}0.08 \pm 0.05 \\
(0.02-0.15)\end{array}$ & $\begin{array}{l}0.04 \pm 0.03 \\
(0.01-0.07)\end{array}$ \\
\hline & Anthracene & $\begin{array}{l}1.05 \pm 1.43 \\
(0.15-5.04)\end{array}$ & $\begin{array}{l}1.26 \pm 0.68 \\
(0.17-1.90)\end{array}$ \\
\hline$\sum \mathrm{LMW}$ & & $\begin{array}{l}7.94 \pm 6.64 \\
(1.14-19.58)\end{array}$ & $\begin{array}{l}2.83 \pm 1.92 \\
(0.43-5.77)\end{array}$ \\
\hline MMW & Fluoranthene & $\begin{array}{l}0.45 \pm 0.26 \\
(0.07-0.86)\end{array}$ & $\begin{array}{l}0.23 \pm 0.15 \\
(0.11-0.53)\end{array}$ \\
\hline & Pyrene & $\begin{array}{l}0.19 \pm 0.18 \\
(0.01-0.55)\end{array}$ & $\begin{array}{l}0.04 \pm 0.04 \\
(0.01-0.08)\end{array}$ \\
\hline & $\begin{array}{l}\text { Benzo } \\
\quad \text { (a)anthracene }\end{array}$ & $\begin{array}{l}0.15 \pm 0.14 \\
(0.01-0.39)\end{array}$ & $\begin{array}{l}0.18 \pm 0.19 \\
(0.01-0.46)\end{array}$ \\
\hline & Chrysene & $\begin{array}{l}0.22 \pm 0.19 \\
(0.02-0.39)\end{array}$ & $0.11 *$ \\
\hline \multicolumn{2}{|l|}{$\sum \mathrm{MMW}$} & $\begin{array}{l}0.65 \pm 0.50 \\
(0.07-1.87)\end{array}$ & $\begin{array}{l}0.42 \pm 0.33 \\
(0.02-0.99)\end{array}$ \\
\hline \multirow[t]{6}{*}{ HMW } & $\begin{array}{l}\text { Benzo } \\
\text { (b)fluoranthene }\end{array}$ & $\begin{array}{l}0.40 \pm 0.59 \\
(0.03-1.85)\end{array}$ & $\begin{array}{l}0.12 \pm 0.10 \\
(0.02-0.32)\end{array}$ \\
\hline & $\begin{array}{l}\text { Benzo } \\
\text { (k)fluoranthene }\end{array}$ & $\begin{array}{l}0.39 \pm 0.49 \\
(0.01-1.57)\end{array}$ & $\begin{array}{l}0.33 \pm 0.48 \\
(0.01-1.27)\end{array}$ \\
\hline & $\begin{array}{l}\text { Benzo } \\
\text { (a)pyrene }\end{array}$ & $\begin{array}{l}0.23 \pm 0.13 \\
(0.04-0.41)\end{array}$ & $\begin{array}{l}0.08-0.1 \\
(0.01-0.23)\end{array}$ \\
\hline & $\begin{array}{l}\text { Dibenzo } \\
\quad(a, h) \text { anthracene }\end{array}$ & $\begin{array}{l}0.87 \pm 0.87 \\
(0.08-2.09)\end{array}$ & $0.03 *$ \\
\hline & $\begin{array}{l}\text { Benzo } \\
\quad(\mathrm{g}, \mathrm{h}, \mathrm{i}) \text { perylene }\end{array}$ & $\begin{array}{l}8.25 \pm 7.90 \\
(1.35-17.40)\end{array}$ & $\begin{array}{l}3.27 \pm 2.15 \\
(1.00-6.23)\end{array}$ \\
\hline & $\begin{array}{l}\text { Indeno } \\
\qquad(1,2,3-c, d) p y r e n e\end{array}$ & $0.55^{*}$ & $\begin{array}{l}5.09 \pm 1.78 \\
(2.97-6.90)\end{array}$ \\
\hline$\sum \mathrm{HMW}$ & & $\begin{array}{l}3.97 \pm 5.76 \\
(0.37-18.87)\end{array}$ & $\begin{array}{l}6.16 \pm 4.27 \\
(1.13-13.37)\end{array}$ \\
\hline$\sum \mathrm{PAH}_{16}$ & & $\begin{array}{l}12.56 \pm 7.88 \\
(2.53-25.36)\end{array}$ & $\begin{array}{l}9.40 \pm 4.64 \\
(4.50-17.49)\end{array}$ \\
\hline
\end{tabular}

$L M W$, low molecular weight PAHs; $M M W$, medium molecular weight PAHs; $H M W$, high molecular weight PAHs

* Single value obtained during sampling (the rest was below the detection limit)

(e.g. $\sum \mathrm{PAH}_{27}$ levels of less than $5 \mathrm{ngm}^{-3}$ were measured in winter months in Athens by Alves et al. 2017). At the same time, concentrations found in Gdynia were significantly lower 
than in highly urbanised polluted areas, where PAH levels can be higher even by an order of magnitude. Mikuska and coauthors (Mikuska et al. 2015) reported $\sum \mathrm{PAH}_{16}$ concentrations in the range of $435-2316 \mathrm{ng} \mathrm{m}^{-3}$ during a 6-day winter smog episode in Ostrava (Czech Republic).

The dominant PAHs detected over the study period were BghiP (mean of 8.25 and $3.27 \mathrm{ngm}^{-3}$ for the heating and nonheating season, respectively) and ACE (mean of 5.96 and 2.42 $\mathrm{ngm}^{-3}$ for the heating and non-heating season, respectively). Both compounds displayed a pronounced seasonality. Slightly lower were the levels of IcdP and NAP. The lowest average concentrations were noted for PHE (mean of 0.08 and 0.04 $\mathrm{ngm}^{-3}$ for the heating and non-heating season, respectively), which is consistent with its partitioning behaviour: due to its characteristics, PHE is mostly found in vapour phase (Ravindra et al. 2008). Average concentrations of DahA and $\mathrm{BaP}$, compounds characterised by the high carcinogenicity, were relatively low and exhibited a similar pattern of elevated concentrations in the heating season (e.g. mean BaP concentrations of 0.23 and $0.08 \mathrm{ng} \mathrm{m}^{-3}$ were obtained for the heating and non-heating season).

Although seasonality in particle-bound PAH concentrations is well described for urbanised regions (Liu et al. 2015; Akyuz and Cabuk 2009), a small number of studies focus on mediumsized coastal cities like Gdynia and aerosols of less than $2.5 \mu \mathrm{m}$ in diameter. Results obtained in Gdynia revealed that the average concentration of $\mathrm{BaP}$ (widely recognised as the representative $\mathrm{PAH}$ ) was approximately three times higher during the heating period relative to the non-heating period $(0.23$ and $0.08 \mathrm{ng} \mathrm{m}^{-3}$, respectively). This was most likely due to the increased coal consumption in the investigated region (Ravindra et al. 2008; Lewandowska et al. 2018b). A pronounced summer-winter variation in PAH concentrations detected in PM2.5 in the coastal zone (Hong Kong) was previously reported by Guo and co-authors (Guo et al. 2003). The mean $\sum \mathrm{PAH}_{16}$ concentration obtained in the summer $(4.87 \mathrm{ng}$ $\mathrm{m}^{-3}$ ) was one order of magnitude lower than that noted in the winter months $\left(41.75 \mathrm{ng} \mathrm{m}^{-3}\right)$. The winter concentrations of PAHs were much higher in Hong Kong compared to those in Gdynia, which can be explained by the much larger population of Hong Kong combined with extensive maritime activity. Moreover, Guo et al. (2003) accounted for the entire winter season. At the same time, they observed BaP seasonality similar to the one seen in our data (winter levels approximately three times higher than summer; a mean of 2.06 and $0.73 \mathrm{ng} \mathrm{m}^{-3}$ in winter and summer, respectively). Comparable values were later reported by Villar-Vidal and co-authors (Villar-Vidal et al. 2014), who found PM2.5-bound BaP concentrations in Spanish coastal cities to range between 0.05 and $0.88 \mathrm{ng} \mathrm{m}^{-3}$. Other PAHs detected in PM2.5 in Gdynia revealed a similar trend with much higher concentrations noted during the heating period (Table 2), further supporting the hypothesis about the negative impact of domestic energy consumption on air quality.
This phenomenon has previously been observed by several authors (Tobiszewski and Namiesnik 2012; Garrido et al. 2014; Lewandowska et al. 2018b).

The sampling location was situated near an industrial part of the city and was heavily influenced by residential heating. However, the trajectory analysis suggested that the highly contaminated air masses were transported from the Silesian Voivodeship in Southern Poland. Meteorological conditions largely determine the behaviour of atmospheric pollutants, and it is likely that the relatively low concentrations of PAHs detected in samples collected in coastal zones are a result of the highly efficient dispersal of contaminants (Lewandowska et al. 2018b).

\section{Sources of PAHs}

Major PAH source types can be differentiated by their species composition profile (i.e., 'fingerprint'), permitting initial source type identification based on the ratio of individual compounds within diagnostic pairs. It is important that species paired for diagnostic ratio analysis have the same molecular mass and properties and are subject to similar transport and reaction processes in the atmosphere (Galarneau 2008; Tobiszewski and Namiesnik 2012). In general, petrogenic sources typically release lighter hydrocarbons, whereas compounds of pyrogenic origin are characterised by a higher molecular mass (Ravindra et al. 2008).

Based on PAHs values obtained in Gdynia in the study period (April 16, 2012-May 15, 2012) the FLA/(FLA + PYR) diagnostic ratio was calculated, revealing that detected PAHs originated from coal or wood combustion during both the heating and non-heating season ( 0.76 and 0.77 , respectively) (De La Torre-Roche et al. 2009). The high mean IcdP/(IcdP+ BghiP) ratio in the heating period (0.97) also pointed at the prevalence of pyrogenic sources in the studied region (Yunker et al. 2002; Ravindra et al. 2008). This further supports the previously stated hypothesis about domestic heating being the dominant PAH source in the first half of the study.

In the non-heating season, the mean IcdP/(IcdP+BghiP) ratio decreased twofold (0.40), which might suggest that the dominant source of PAHs changed from coal combustion to a petrogenic origin (Yunker et al. 2002; Hanedar et al. 2014). This was likely caused by the sampler's proximity to several busy roads. The prevailing PAHs in the study period included ACE, NAP, BghiP and IcdP (Table 2), the first two typically emitted as a result of coal combustion (Tasdemir and Esen 2007), which could explain their elevated levels in the heating season. Concentrations of both decreased in the beginning of the non-heating period, whereas the dominant PAHs changed to BghiP and IcdP, commonly used as proxies for diesel engine emission (Yilmaz and Davis 2016). The lowest $\mathrm{IcdP} /(\mathrm{IcdP}+\mathrm{BghiP})$ ratio noted over the analysed period was 0.14 (April 30,2012) and could have been associated with the emission of PAHs from diesel engines (Yunker et al. 2002). 
Furthermore, hydrocarbons composed of three benzene rings were dominant throughout the entire sampling period $(40.7 \%)$, with the percentage of highly carcinogenic 6-ring substances being slightly lower (30\%). Such elevated abundances of 3- and 6-ring hydrocarbons have been found to be representative of diesel engine emissions (Yunker et al. 2002), which might suggest that the busy street located near the sampling device might have been a source of PAHs during the entire study, or that the prevalent winds blowing from the west carried contaminants from the adjacent bypass (Witkowska and Lewandowska 2016). Notably, a high (31\%) percentage of vehicles registered in Gdynia are equipped with diesel engines that reportedly contribute to PAH pollution (https://bdl. stat.gov.pl). The mean $\mathrm{BaA} /(\mathrm{BaA}+\mathrm{Chr})$ value (0.55) seems to further confirm the contribution of this source to the overall air pollution in Gdynia (Akyuz and Cabuk 2009).

It is also likely that the change of dominant source from pyrogenic into petrogenic was caused by maritime transport. The Baltic Sea is characterised by a high marine traffic, with $80 \%$ of cruise ships being able to accommodate more than 3,000 people. Most cruises take up to $20 \mathrm{~h}$ and are especially popular during warmer months. In this study, high concentrations of IcdP and BghiP seem to have been associated with an intensification of maritime activity in the port of Gdynia (Stankiewicz et al. 2010). For example, low IcdP/(IcdP+ BghiP) ratios were noted for May 01-02, 2012 and May 0609, 2012 (0.47 and 0.36, respectively). Such a pronounced trend was not obtained for ANT/(ANT+PHE), which did not display weekday/weekend variations and remained low (mean $=0.03$ ) throughout the entire non-heating period, suggesting a petrogenic origin of PAHs. In addition to passenger vessels, the local port serves cargo and tank ships that, back in 2012, used heavy fuel oil and possibly emitted large amounts of HMW PAHs without a clear weekend schedule (Adams et al. 2014). Starting 2015, the Baltic Sea has become an Emissions Control Area and vessels now have to comply with strict $\mathrm{SO}_{\mathrm{x}}$ emission limits (Jonson et al. 2019). Nevertheless, it has been suggested that sea shipping might still be a significant source of airborne pollutants in Gdynia (Lewandowska et al. 2018a, b). Despite the new regulations, the increasing shipping in the port of Gdynia can cause an adverse effect on the environmental health of the particularly vulnerable, landlocked Baltic Sea (Stankiewicz et al. 2010).

To further support the PAH source investigation, a pollution rose was generated (Fig. 2). The analysis revealed that throughout the whole investigated period, PAHs predominantly originated from domestic heating in the Kashubian region and the port of Gdynia. Although diagnostic ratios suggested that road traffic contributed to PAH emission, it is probably coal combustion in the domestic sector and sea vessel activity that had the greatest influence on the detected levels of PAHs.

\section{Deposition flux of PM2.5 and associated PAHs}

Once emitted, PAHs can be removed from the atmosphere via two major pathways: (i) photodegradation or (ii) wet and dry deposition. The latter have been found to be the most effective for particulate-bound PAHs. As a consequence, PAHs tend to accumulate in soil, as well as aquatic sediments (Ravindra et al. 2008). This is especially important in the case of heavy PAHs that bind to aerosols and undergo slow biodegradation in the natural environment. Their deposition velocity depends on the particle size and a range of meteorological parameters (e.g. air temperature or humidity) (Fang et al. 2004). Because of their high carcinogenic and mutagenic potential and the apparent tendency to accumulate in animal and plant tissues, it is crucial to assess the flux of PM 2.5-bound PAHs.
Fig. 2 Pollution rose showing the relative contribution of different sources (represented by wind directions) to PAH pollution throughout the investigated period

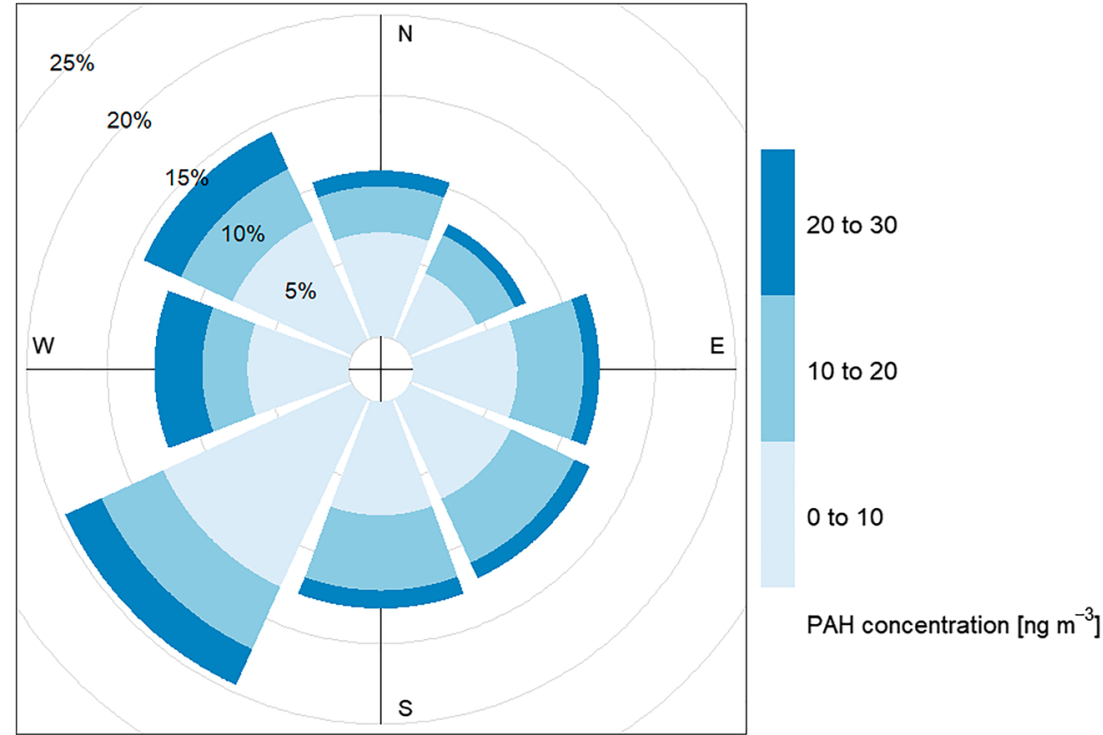


The quantified dry deposition flux of PAHs displayed variations over the analysed period (Fig. 3). The flux of medium weight compounds did not reveal significant variations, which were most likely the result of its less pronounced sorption/ desorption kinetics (Ravindra et al. 2008).

Conversely, temporal variations were much more pronounced for PAHs of low and high molecular weight. The average dry deposition flux was estimated at $528 \mathrm{ng} \mathrm{m}^{-2}$ $\mathrm{day}^{-1}$. In general, the highest values were obtained for HMW PAHs, followed by slightly lower numbers quantified for LMW PAHs (792 and $698 \mathrm{ng} \mathrm{m}^{-2}$ day $^{-1}$, respectively). The mean total daily flux of PAHs was estimated at $4923 \mathrm{ng}$ $\mathrm{m}^{-2}$ day ${ }^{-1}$, which is comparable to the value reported by Terzi and Samara (2005) for a coastal sampling point located in Greece $\left(3917 \mathrm{ng} \mathrm{m}^{-2}\right.$ day $^{-1}$ ). Much higher values are often noted for highly urbanised and industrial regions. For example, Fang and co-authors (Fang et al. 2004) estimated dry deposition fluxes of total PAHs to be as high as $58,500 \mathrm{ng}$ $\mathrm{m}^{-2}$ day $^{-1}$ in the industrial area in Taiwan.

At the same time, the dry deposition flux was decreased twofold after the heating season ended ( 65 and $28 \mathrm{ng} \mathrm{m}^{-2} \cdot \operatorname{season}^{-1}$, for the heating and non-heating period), once again pointing at the significance of domestic heating in the studied region. Sixtythree percent of PAHs emitted during the heating period were of low molecular weight, with only $32 \%$ HMW PAHs contributing to the overall flux. In the non-heating season, however, the trend reversed and HMW compounds dominated over the lighter hydrocarbons (66 and 30\%, respectively). Although the relatively high abundance of HMW PAHs in the non-heating season could be explained by the continuing emission of PAHs in individual households, the diagnostic ratios suggest that the 6-ring PAHs were most likely emitted by transport, both land and marine. Further, the analysis of air trajectories revealed that the highdry deposition flux values obtained for HMW PAHs corresponded to air masses being delivered from the harbour area (north and north-west). For example, a very high total daily flux of PAHs (5841 ng m${ }^{-2}$ day $^{-1}$ ) was noted on May 06-09, 2012, which corresponded to wind advection from the seaport (Fig. 4a). The low IcdP/(IcdP+BghiP) ratio (0.36) confirmed that pollutants most likely originated then from sea vessel emission (Yunker et al. 2002). This particular weekend marked a bank holiday and a subsequent increase in cruise ship activity, which contributed to a higher emission of PAHs.

The highest total flux of $\sum \mathrm{PAHs}_{16}$ was noted in the heating period, on April 17-18, 2012. The FLA/(FLA + PYR) ratio of 0.78 suggested an existing pyrogenic source of airborne pollutants (De La Torre-Roche et al. 2009). In this case, the analysis of air trajectories revealed that air masses were advected from the local bypass, as well as the Kashubian region (WSW, Fig. 4b). This observation further confirmed the relatively high contribution of domestic heating and road traffic to the air quality of Gdynia.

\section{The carcinogenic potential of PAHs based on the BaP equivalent method}

Over the analysed period, the average $\mathrm{BaP}$ equivalent concentration was estimated at $0.9 \mathrm{ng} \mathrm{m}^{-3}$. Similar values have previously been found in Florence, Italy $\left(0.79 \mathrm{ng} \mathrm{m}^{-3}\right)$ (Martellini et al. 2012) and Hamilton, Canada $\left(0.84 \mathrm{ng} \mathrm{m}^{-3}\right.$ ) (Anastasopoulos et al. 2012). At the same time, much higher values have been reported in

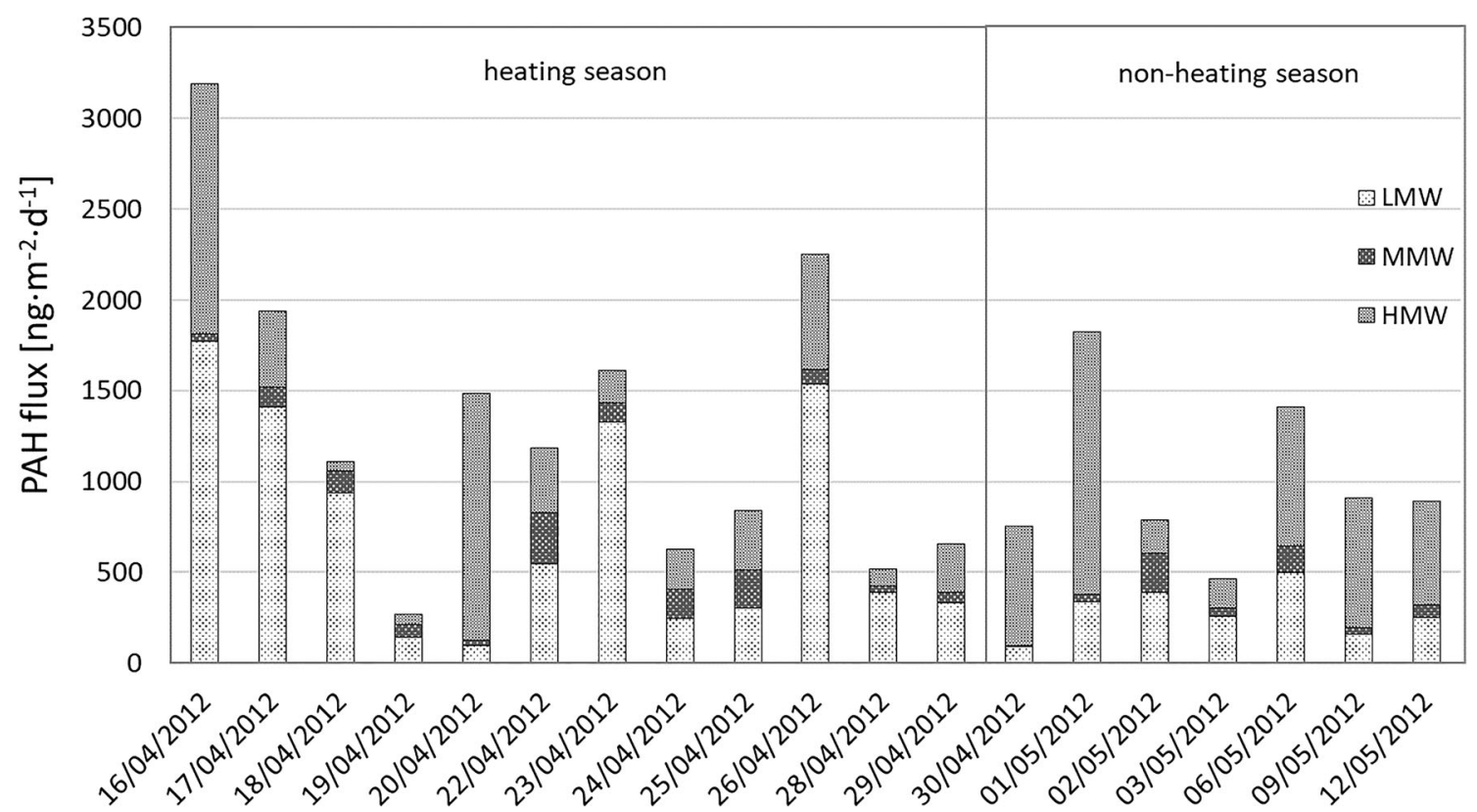

Fig. 3 Variability of the total dry deposition PAH flux over the investigated period 

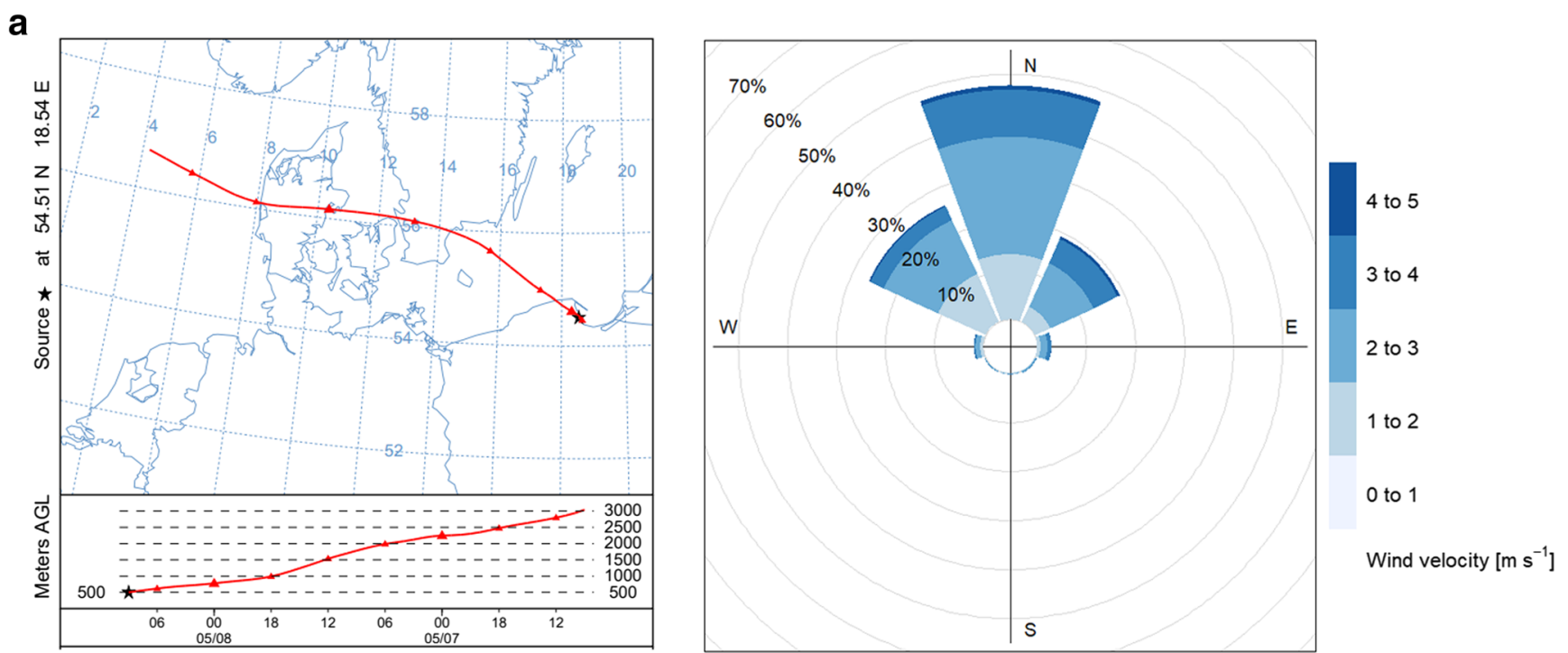

b
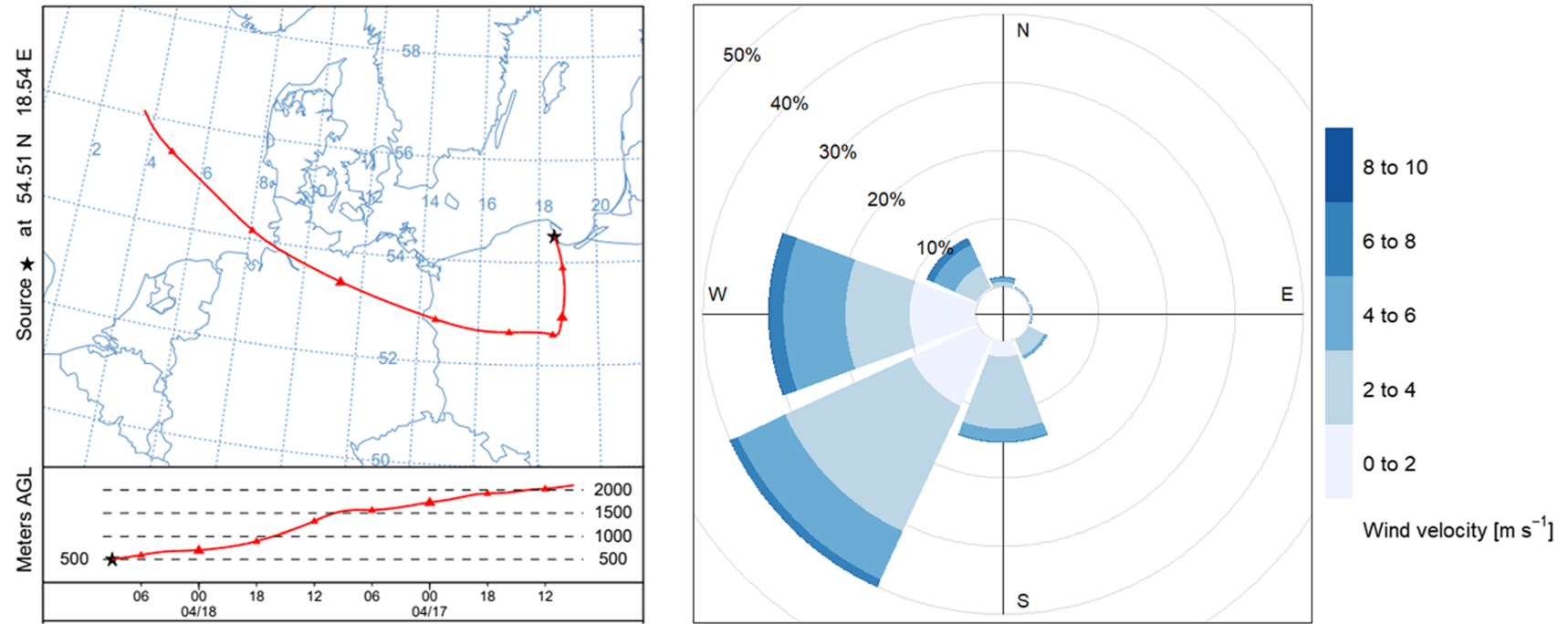

Fig. 4 Air mass trajectories (http://ready.arl.noaa.gov/HYSPLIT.php) and wind roses on a May 06, 2012-May 09, 2012 and b April 16-18, 2012 in Gdynia

industrial, densely populated and polluted regions such as Guangzhou, China ( $\max =22.46 \mathrm{ng} \mathrm{m}^{-3}$ ) (Liu et al. 2015).

The mean BaPE was significantly higher during the heating period relative to the non-heating season $(0.81$ and $0.48 \mathrm{ng} \mathrm{m}^{-3}$ ), again pointing at domestic heating sources of PAHs contributing to the overall air quality of Gdynia over the analysed period. On April 22, 2012 (Sunday) the carcinogenic potential reached $1.4 \mathrm{ng} \mathrm{m}^{-3}$ as a result of elevated concentrations of highly mutagenic DahA and BF detected in PM2.5 aerosols. This peak was most likely to the prevailing southerly winds, which could have caused an advection of contaminants from the highly polluted Kashubian region or the local bypass during weekend road traffic.

\section{Conclusions}

The average concentrations of PAHs detected in PM2.5 aerosols in Gdynia were found to be relatively low throughout the whole study. PAH levels were generally higher during the heating season. That was likely due to PAH emission associated with fossil fuel combustion for domestic heating (pyrogenic sources). However, concentrations of highly carcinogenic heavy hydrocarbons increased during the non-heating season as a result of sea shipping in the Gulf of Gdansk (petrogenic source). At the same time, it is possible that a large portion of PAHs originated from diesel engine emissions. Levels of hazardous compounds associated with small aerosols should be carefully monitored throughout the upcoming 
years, so appropriate measures can be taken. Although domestic heating and vehicle emission remain the main contributors to air pollution in Poland, it is important to account for all of the possible PAH sources. Obtained results suggest that in coastal locations, maritime emission might be underestimated and should receive more attention. This is especially crucial given the ongoing rapid expansion of sea shipping on the global scale and its increasing effect on air quality.

Open Access This article is distributed under the terms of the Creative Commons Attribution 4.0 International License (http:// creativecommons.org/licenses/by/4.0/), which permits unrestricted use, distribution, and reproduction in any medium, provided you give appropriate credit to the original author(s) and the source, provide a link to the Creative Commons license, and indicate if changes were made.

\section{References}

ACEA (2017) Report: Vehicles in use - Europe 2017. European Automobile Manufacturers Association. https:/www.acea.be/ statistics/article/vehicles-in-use-europe-2017. Accessed 12 July 2019

Adams J, Bornstein JM, Munno K, Hollebone B, King T, Brown RS, Hodson PV (2014) Identification of compounds in heavy fuel oil that are chronically toxic to rainbow trout embryos by effects-driven chemical fractionation. Environ Toxicol Chem 33:825-835. https:// doi.org/10.1002/etc.2497

Akyuz M, Cabuk H (2009) Meteorological variations of PM2.5/PM10 concentrations and particle-associated polycyclic aromatic hydrocarbons in the atmospheric environment of Zonguldak, Turkey. J Hazard Mater 170:13-21. https://doi.org/10.1016/j.jhazmat.2009. 05.029

Alves CA, Vicente AM, Custódio D, Cerqueira M, Nunes T, Pio C, Lucarelli F, Calzolai G, Nava S, Diapouli E, Eleftheriadis K, Querol X, Musa Bandowe BA (2017) Polycyclic aromatic hydrocarbons and their derivatives (nitro-PAHs, oxygenated PAHs, and azaarenes) in PM2.5 from Southern European cities. Sci Total Environ 595:494 504. https://doi.org/10.1016/j.scitotenv.2017.03.256

Anastasopoulos AT, Wheeler AJ, Karman D, Kulka RH (2012) Intraurban concentrations, spatial variability and correlation of ambient polycyclic aromatic hydrocarbons (PAH) and PM 2.5. Atmos Environ 59: 272-283. https://doi.org/10.1016/j.atmosenv.2012.05.004

Błaszczyk E, Mielżyńska-Švach D (2016) Polycyclic aromatic hydrocarbons and PAH-related DNA adducts. J Appl Genetics 58:321-330. https://doi.org/10.1007/s13353-016-0380-3

Ćwiklak K, Pastuszka JS, Rogula-Kozłowska W (2009) Influence of traffic on particulate-matter polycyclic aromatic hydrocarbons in urban atmosphere of Zabrze, Poland. Pol J Environ Stud 18(4): $579-585$

De La Torre-Roche RJ, Lee WY, Campos-Díaz SI (2009) Soil-borne polycyclic aromatic hydrocarbons in El Paso, Texas: Analysis of a potential problem in the United States/Mexico border region. J Hazard Mater 163:946-958. https://doi.org/10.1016/j.jhazmat. 2008.07.089

EEA, European Environment Agency (2018) Air quality in Europe 2018 report. Publications Office of the European Union, Luxembourg, p 88. https://doi.org/10.2800/285124 Accessed 12 July 2019

Eeftens M, Tsaib M, Ampee C, Anwanderf B, Beelena R, Bellanderg T, Cesaronih G, Cirachi M, Cyrysl J, Hooghm K, De Nazellei A, Vochtn F, Declercqo C, Dédelèp A, Eriksenq K, Galassir C,
Gražulevičienèp R, Grivass G, Heinrichl J, Hoffmann B, Iakovidesu M, Ineichenb A, Katsouyanniv K, Korekg M, Krämert U, Kuhlbuschw T, Lankix T, Madseny C, Meliefstea K, Möltern A, Moslerm G, Nieuwenhuijseni M, Oldenweninga M, Pennanenx A, Probst-Henschb Quassw N, Raaschou-Nielsen O, Ranziz Stephanouu E, Sugirit D, Udvardyaa O, Vasköviaa E, Weinmayrt G, Brunekreefa B, Hoeka G (2013) Spatial variation of PM2.5, PM10, PM2.5 absorbance and PMcoarse concentrations between and within 20 European study areas and the relationship with $\mathrm{NO}_{2}$ - results of the ESCAPE project. Atmos Environ 62:303-317. https://doi.org/10.1016/j.atmosenv.2012.08.038 Accessed 12 July 2019

Fang G, Chang K, Liu C, Hsunling B (2004) Estimation of PAHs dry deposition and $\mathrm{BaP}$ toxic equivalency factors (TEFs) study at Urban, Industry Park and Rural Sampling Sites in Central Taiwan, Taichung. Chemosphere 55:787-796. https://doi.org/10.1016/j. chemosphere.2003.12.012

Galarneau E (2008) Source specificity and atmospheric processing of airborne PAHs: Implications for source apportionment. Atmos Environ 42:8139-8149. https://doi.org/10.1016/j.atmosenv.2008. 07.025

Garrido A, Jimenez-Guerrero P, Ratola N (2014) Levels, trends and health concerns of atmospheric PAHs in Europe. Atmos Environ 99:474-484. https://doi.org/10.1016/j.atmosenv.2014.10.011

Guo H, Lee SC, Ho KF, Wang XM, Zou SC (2003) Particle-associated polycyclic aromatic hydrocarbons in urban air of Hong Kong. Atmos Environ 37:5307-5317. https://doi.org/10.1016/j.atmosenv. 2003.09.011

Hanedar A, Alp K, Kaynak B, Avșarb E (2014) Toxicity evaluation and source apportionment of Polycyclic Aromatic Hydrocarbons (PAHs) at three stations in Istanbul, Turkey. Sci Tot Environ 488489:437-446. https://doi.org/10.1016/j.scitotenv.2013.11.123

Hoyle CR, Boy M, Donahue NM, Fry JL, Glasius M, Guenther A, Hartz KH (2011) A review of the anthropogenic influence on biogenic secondary organic aerosol. Atmos Chem Phys 11:321-343. https:// doi.org/10.5194/acp-11-321-2011

Iwanek J, Kobus D, Mitosek G, Parvi R (2016) Air pollution with polycyclic aromatic hydrocarbons at urban background stations in 2015. Institute of Environmental Protection (in Polish). http://powietrze. gios.gov.pl/pjp/publications/card/2058. Accessed 03 July 2019

Jonson EJ, Gauss M, Jalkanen JP, Johansson L (2019) Effects of strengthening the Baltic Sea ECA regulations. Atmos. Chem. Phys. Discuss.:1-15. https://doi.org/10.5194/acp-2019-51

Karali D, Rapsomanikis S, Christoforidis A (2018) Kinetic behavior of non-volatile PAHs associated with urban aerosol. Air Qual Atmos Health 11:825-833. https://doi.org/10.1007/s11869-018-0590-4

Ladji R, Yassaa N, Balducci C, Cecinato A (2014) Particle size distribution of n-alkanes and polycyclic aromatic hydrocarbons (PAHS) in urban and industrial aerosol of Algiers, Algeria. Environ Sci Pollut 21:1819-1832. https://doi.org/10.1007/s11356-013-2074-2

Lewandowska A, Beldowska M, Witkowska A, Falkowska L, Wisniewska K (2018a) Mercury bonds with carbon (OC and EC) in small aerosols (PM1) in the urbanized coastal zone of the Gulf of Gdansk (southern Baltic). Ecotox Environ Safe 157:350-357. https://doi.org/10.1016/j.ecoenv.2018.03.097

Lewandowska AU, Staniszewska M, Witkowska A, Machuta M (2018b) Benzo(a)pyrene parallel measurements in PM1 and PM2.5 in the coastal zone of the Gulf of Gdansk (Baltic Sea) in the heating and non-heating seasons. Environ Sci Pollut 25:19458-19469. https:// doi.org/10.1007/s11356-018-2089-9

Liu J, Man R, Ma S, Li J, Wu Q, Peng J (2015) Atmospheric levels and health risk of polycyclic aromatic hydrocarbons (PAHs) bound to PM 2.5 in Guangzhou, China. Mar Pollut Bull 100:134-143. https:// doi.org/10.1016/j.marpolbul.2015.09.014

Martellini T, Giannoni M, Lepri L, Katsoyiannis A, Cincinelli A (2012) One year intensive PM2.5 bound polycyclic aromatic hydrocarbons 
monitoring in the area of Tuscany, Italy. Concentrations, source understanding and implications. Environ Pollut 164:252-258. https://doi.org/10.1016/j.envpol.2011.12.040

Mikuska P, Krumal K, Vecera Z (2015) Characterization of organic compounds in the PM2.5 aerosols in winter in an industrial urban area. Atmos Environ 105:97-108. https://doi.org/10.1016/j.atmosenv. 2015.01.028

Ravindra K, Sokhi R, Van Grieken R (2008) Atmospheric polycyclic aromatic hydrocarbons: Source attribution, emission factors and regulation. Atmos Environ 42:2895-2921. https://doi.org/10.1016/j. atmosenv.2007.12.010

Rodhe H, Söderlund R, Ekstedt J (1980) Deposition of airborne pollutants on the Baltic. Ambio 9:168-173

Rogula-Kozłowska W, Klejnowski K, Rogula-Kopiec P, Ośródka L, Krajny E, Błaszczak B, Mathews B (2014) Spatial and seasonal variability of the mass concentration and chemical composition of PM2.5 in Poland. Air Qual Atmos Health 7:41-58. https://doi.org/ 10.1007/s11869-013-0222-y

Sánchez de la Campa AM, Pio C, de la Rosa JD, Querolc X, Alastuey A, González-Castanedob Y (2009) Characterization and origin of EC and $\mathrm{OC}$ particulate matter near the Doñana National Park (SW Spain). Environ Res 109:671-681. https://doi.org/10.1016/j. envres.2009.05.002

Seinfeld JH, Pandis SN (2016) Atmospheric Chemistry and Physics from Air Pollution to Climate Change, 3rd edn. Wiley, New York

Stankiewicz M, Backer H, Vlasov N (2010) Maritime Activities in the Baltic Sea. An integrated thematic assessment on maritime activities and response to pollution at sea in the Baltic Sea Region. HELCOM. http://www.helcom.fi/Lists/Publications/BSEP123.pdf. Accessed 07 August 2019

Stein AF, Draxler RR, Rolph GD, Stunder BJB, Cohen MD, Ngan F (2015) NOAA's HYSPLIT atmospheric transport and dispersion modeling system. Bull Amer Meteor Soc 96:2059-2077. https:// doi.org/10.1175/BAMS-D-14-00110.1 Accessed 03 July 2019

Styszko K, Samek L, Szramowiat K, Korzeniewska A, Kubisty K, Rakoczy-Lelek R, Kistler M, Kasper Gieb A (2017) Oxidative potential of PM10 and PM2.5 collected at high air pollution site related to chemical composition: Krakow case study. Air Qual Atmos Health 10:1123-1137. https://doi.org/10.1007/s11869-0170499-3

Tasdemir Y, Esen F (2007) Dry deposition fluxes and deposition velocities of PAHs at an urban site in Turkey. Atmos Environ 41:12881301. https://doi.org/10.1016/j.atmosenv.2006.09.037

Terzi E, Samara C (2005) Dry deposition of polycyclic aromatic hydrocarbons in urban and rural sites of Western Greece. Atmos Environ 39:6261-6270. https://doi.org/10.1016/j.atmosenv.2005.06.057

Tobiszewski M, Namiesnik J (2012) PAH diagnostic ratios for the identification of pollution emission sources. Environ Pollut 162:110 119. https://doi.org/10.1016/j.envpol.2011.10.025

Villar-Vidal M, Lertxundi A, López de Dicastillo M, Alvarez J, Santa Marina Ayerdi M, Basterrechea M, Ibarluzea J (2014) Air polycyclic aromatic hydrocarbons (PAHs) associated with $\mathrm{PM}_{2.5}$ in a North Cantabric coast urban environment. Chemosphere 99:233-238. https://doi.org/10.1016/j.chemosphere.2013.11.006

Witkowska A, Lewandowska AU (2016) Water soluble organic carbon in aerosols (PM1, PM2.5, PM10) and various precipitation forms (rain, snow, mixed) over the southern Baltic Sea station. Sci Total Environ 573:337-346. https://doi.org/10.1016/j.scitotenv.2016.08.123

Yilmaz N, Davis SM (2016) Polycyclic aromatic hydrocarbon (PAH) formation in a diesel engine fueled with diesel, biodiesel and biodiesel/n-butanol blends. Fuel 181:729-740. https://doi.org/10. 1016/j.fuel.2016.05.059

Yunker MB, MacDonald RW, Vingarzan R, Mitchell RH, Goyette D, Sylvestre S (2002) PAHs in the Fraser River basin: a critical appraisal of PAH ratios as indicators of PAH source and composition. Org Geochem 33:489-515. https://doi.org/10.1016/S0146-6380(02) 00002-5

Publisher's note Springer Nature remains neutral with regard to jurisdictional claims in published maps and institutional affiliations. 